basada en el empleo del adobe y diversas técnicas constructivas ancestrales, como las bóvedas nubias erigidas sin cimbra, las cúpulas, los patios o los captadores de viento.

Estos principios fueron desarrollados en el que sería el encargo más relevante de su trayectoria: la construcción de Nuevo Gourna (1946-1952), la ciudad que habría de realojar a los habitantes del antiguo asentamiento, lejos del área arqueológica donde se implantaba. El trazado inacabado de este pequeño núcleo urbano de Luxor responde a la reinterpretación de la tradición urbanística y arquitectónica desde el apego a la cultura autóctona, traducida en el uso racional de materiales y técnicas locales de acuerdo con una extraordinaria sensibilidad hacia los problemas climáticos.

En pleno siglo XXI, ante los retos suscitados por el cambio climático y la pérdida de identidad a causa de la globalización, la arquitectura de Fathy está más vigente que nunca. De ahí que la publicación del catálogo Hassan Fathy, a contracorriente resulte especialmente oportuna. El libro recoge diversos ensayos suscritos por especialistas, alternados con una selección de la obra construida del arquitecto egipcio y sus peculiares dibujos. José Tono Martínez, coordinador del catálogo y comisario de la exposición, ofrece al inicio una visión global con la puesta en valor del protagonista; Serge Santelli, Leila el-Wakil, Nadia Radwan y María Pura Moreno aportan sus propias interpretaciones críticas; mientras que Fernando Vegas, Camilla Mileto y Valentina Cristini complementan la publicación con un texto sobre la arquitectura de tierra en España.

José Tono Martínez (coord.)

Hassan Fathy: a contracorriente Ediciones Asimétricas, 2021

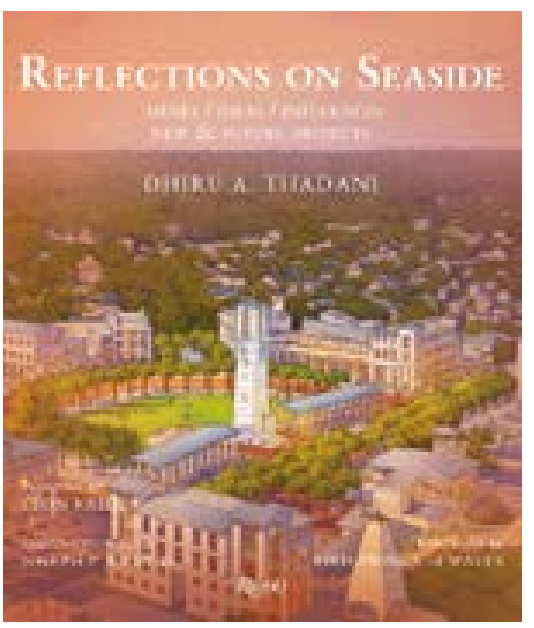

improvement to the urban form of the town: Thadani's own design connecting the Town Center to the Lyceum. This is beautifully illustrated in Steven Hurtt's essay, "Of Modest Grandeur and the Affordance of Intimacy.”

Despite its sophistication and importance, the Seaside plan had two major flaws. One is that the Central Square was too big. The other, more important one, was that the buildings defining the Central Square had a public "front" to the square and a service "back" to the spatially incomplete Lyceum and residential fabric behind, thus disconnecting the square from the fabric.

\section{The Central Square: Lyceum Set-Piece}

\section{La Central Square unida al Lyceum de Seaside}

\section{A Praça Central do Lyceum de Seaside}

\section{Michael Dennis}

Dhiru Thadani has just produced his second massive book on the tiny beach town, Seaside, Florida. Reflections on Seaside joins his earlier Visions of Seaside as well as Views of Seaside, a still earlier volume produced by the Seaside Institute. In terms of number and area of pages, these three volumes are almost equal (95\%) to Edward Gibbon's The History of the Rise and Fall of the Roman Empire. Can this small, designed, community support this degree of attention? Possibly. Although Seaside has been reviled by many modernist architects who resent its style and success, it is important for its urbanism well beyond its size and neo-traditional style. Reflections contains 132 essays by ninety contributors. These essays are organized in four chapters: "Muses," "Ideas," "Influences," and "New \& Future Projects." Within these mostly short, mostly interesting, Reflections, however, there is a very important
Dhiru Thadani's design to connect the Central Square through Dan Solomon's arched opening to the Lyceum is a miraculously beautiful and effective solution to the problem. It is, in fact, so effective that it is hard to see that there ever was a problem to be solved -but there were many. They are now invisible due to the ingenious design. These many problems, and their solutions, are described and illustrated by Thadani in his essay, "The Lyceum Colonnade."

The concept of the project is simple: a continuous colonnade unites the detached buildings and defines the central space of the Lyceum, similar to Jefferson's Lawn at the University of Virginia. The far end is closed by a semi-circle of the colonnade framing a stage; the entrance from the Central Square side is framed by symmetrical stairs leading to the second level. The connection of the Lyceum to the Central Square is accomplished by a slightly raised "neck" crossing Quincy Circle. This neck, Quincy Plaza, is defined by paving and palm trees. The resulting sequence of Central Square, Portal, Quincy Plaza, and Lyceum is so beautifully clear and compelling that one hardly notices passing through the service backs of buildings.

This unifying urban ensemble is designed at the intersection of urban design, architecture, landscape, and the minutia of construction. It is what 
practice should be -architecture and landscape in the service of urbanism. It also illustrates the value of incremental development and correction, like the evolution of Seaside itself. For this reviewer this intervention is worth the massiveness of the tome. The connection of the Lyceum to the Central Square is one of many recent improvements to Seaside's public spaces that are illustrated in Reflections on Seaside.

\section{Dhiru Thadani}

Reflections on Seaside Rizzoli, 2021

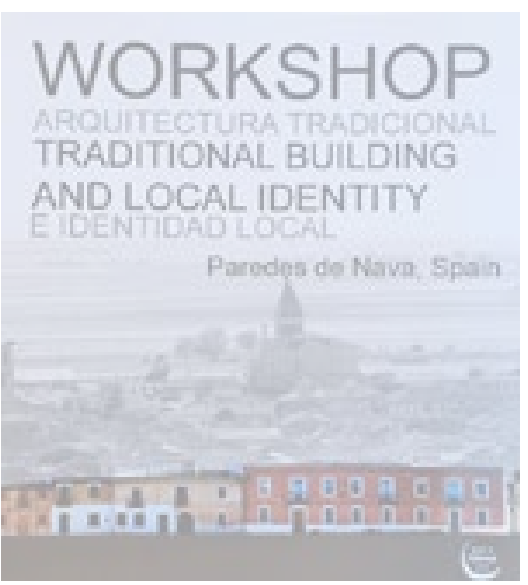

público involucra a los asistentes en un intenso debate estético y funcional, que crea un espacio abierto donde compartir experiencias. La suma de todas las propuestas permite obtener unas directrices de actuación, con la intención de, mediante la mejora del espacio público, poner en valor el municipio. En definitiva, se busca innovar a partir de la tradición, encontrar soluciones sencillas y saludables, y, finalmente, ser capaces de autogestionar los recursos.

El libro Workshop arquitectura tradicional e identidad local recoge las experiencias del primero de los dos Talleres que "Made in Tierra Spain" desarrolló bajo este título en Paredes de Nava en los años 2018 y 2019.

\section{Experimental Earthen}

Building in Paredes de Nava

\section{Paredes de Nava: Un \\ espacio rural experimental}

\section{Paredes de Nava: Um espaço rural experimental}

\section{José Ma García de Acilu}

Paredes de Nava (Palencia, España) cuenta con una importante arquitectura de tierra, un auténtico catálogo vivo de soluciones y técnicas constructivas, que uno puede encontrar tanto en grandes iglesias como en casas, casonas, casetas, naves, corrales, o, incluso, palomares. Muy variado es, además, el muestrario de técnicas con las que la tierra es aplicada: adobe, tapia, tapia encadenada, entramados, revocos de tierra, en combinación con ladrillo, piedra, madera... Se trata de una arquitectura hecha de materiales naturales, cercanos, casi sin procesar, que se ha adaptado al lugar y responde a sus necesidades: una lección de sostenibilidad.

Durante una semana al año, el pueblo se convierte en un campo experimental internacional, en el que el diseño colaborativo del espacio
En ellos se planteó una reflexión sobre la entidad del espacio público del pueblo en relación directa con la arquitectura que lo contextualiza, con la intención de encontrar soluciones que dialoguen con la estética y la compatibilidad técnica y de materiales de la arquitectura del entorno, que sea capaz de regenerar el espacio público respetando lo existente, dotándolo de carácter, y evitando así transferir al lugar soluciones urbanas típicas "de ciudad” o simplemente "de catálogo".

Esta actividad tiene como objetivo investigar, experimentar, recuperar el conocimiento técnico, y trasmitirlo de forma que se forme a los participantes en la regeneración urbana integral del medio rural. Al mismo tiempo, se busca iniciarlos en el uso de la tierra como material de construcción. Todo ello queda bien plasmado en este volumen.

Àngels Castellarnau Visús, Pilar Diez Rodríguez, Miguel Macho Villameriel, Ignacio Represa Bermejo, Sebastiano D'Urso

Workshop arquitectura tradicional e identidad local

Assur - Laboratorio Cultural, 2020 